\title{
To Explore the Manifestation of Linguaculture Potentials in the English Lecturer's Teaching
}

\author{
Peng Zhu ${ }^{1}$ Dr. Denchai Prabjandee ${ }^{2}$ Dr. Punwalai Kewara ${ }^{3}$ \\ 1.School of Foreign Languages and Literature, Chuxiong Normal University, 546 South Lucheng Road, \\ Chuxiong 675000, China \\ 2.Lecturer, Department of International Graduate Studies in Human Resource Development, Burapha University, \\ Bangsaen 20000, Thailand \\ 3.Assistant Professor, Department of International Graduate Studies in Human Resource Development, Burapha \\ University, Bangsaen 20000, Thailand \\ * Email of the corresponding author: alex.watermelon@hotmail.com
}

\begin{abstract}
This study was attempted to explore what sorts of linguaculture potentials had been manifested by English language lecturers, and how did the lectures manifest the linguaculture potentials in English class. In general, this study applied qualitative research thoroughly. Data collection was collected in in-class observation, in which seven classes had been observed in a sum. Coding derived from the in-class observation transcript was separately analyzed, by then findings were synthesized as themes to illustrate the main points of linguaculture implements in English class. Based on the themes, there were two aspects presented from the findings. The first one was the ways of linguaculture incorporation, and second was the content of linguaculture incorporation. The study suggested the innovation in linguaculture implemented English teaching.
\end{abstract}

Keywords: key words, linguaculture implements, effect, English class

DOI: $10.7176 / \mathrm{JEP} / 11-33-02$

Publication date: November $30^{\text {th }} 2020$

\section{Introduction}

As to an effective language learning, linguistic practice and cultural practice has been considered generally for decades. At present, English is taught and learned as an international or global language, therefore English as a Lingua Franca has been transferred and applied in sorts of studies, therefore, we can easily notice that recent language lecturers, especially English lecturers not only exclusive to English teaching, but also use English into intercultural communication as well. Due to the communicative role of language in communication classroom, which requires lecturers are well equipped with both language proficiency and intercultural awareness. Eventually, the study is to observe linguaculture experience implements in English class. Research question facilitate the researcher engaged in exploring the linguaculture implements in English class.

1. What sorts of linguaculture potentials had been manifested by the lecturer in English class?

2. How did the lecturer manifested the potentials in the English class?

\section{Linguaculture}

Generally, the term linguaculture was introduced by Friedrich (1989), then Agar (1994) adapted and extent the notion of the term. Thereafter, Risager (2005) explained that the concept of linguaculture was generated by some of the linguistic anthropologist who emphasized the inevitable interaction between language and culture. By then linguaculture typically presented the interface between language and culture, eventually the term of linguaculture has been applied in language learning and teaching, and some research field the sociocultural linguistics. Since Agar (1994) combined the term linguaculture to present the interface between culture and culture, linguaculture emphasized two aspects in language and culture (Agar 1994). Initially, the term lingua not only refers to vocabularies and semantic structures in language, but also refers to certain discourse in language practice in specific. And as to the term culture in linguaculture not only exclusive to the lexical and grammatical meaning coexist with the language, but to illustrate the linguistic and semantic meaning in certain discourse.

\subsection{Dimensions of linguaculture}

Generally, in the study of linguaculture implement is the study of the various kinds of linguistic and cultural function carried out and produced by language practice in both language teaching and learning process in class. According to Diaz (2016) suggests that distinguish three dimensions of linguaculture supported clarify three cultural perspectives on language practice in teaching and learning, which are: the semantic and pragmatic potential, the poetic potential, and the identity potential (Diaz 2016).

The first potential was the semantic and pragmatic potential had been presented in intercultural pragmatics and contrastive semantics, which also has been practiced in certain social and personal variability in language use (Diaz 2016). 
The poetic potential was related to the phonological and syllabic structure of the language. Especial language practice in specific kinds of creative meaning in use (Diaz 2016).

The identity potential, namely as social meaning. This potential was related to the social variation of the language use in a specific way, with personal identify of language use in certain discourse, semantics (Diaz 2016). According to Agar (1994) stressed that the language user's linguaculture of the individual cannot be isolated from individual life history, certain social background and cultural identity. In general, Linguaculture is related to one or more specific languages. The concept is more theoretically implemented on language and related culture. But the cultural practice of language should also embrace the discourse.

\section{Research Methodology}

The purpose of this research was to explore how English lecturers incorporate their linguaculture experience in their English teaching. Based on this purpose, qualitative research was legitimate as a methodological frame for this study. Alison (2005) mentioned qualitative research process oriented in which the researcher engages oneself into the field to collect raw data, since qualitative research present the vivid process of the research.

\subsection{Participants}

Creswell (2007) mentioned that the number of participants in qualitative study normally focus on a certain small group. Therefore, considering my research question and research methodology, the scale of potential participants in this study had been narrowed down to Chinese English lecturers, who was teaching courses related to Integration English, English communication, intercultural communication, English speaking, at the School of Foreign Languages and Literature, Chuxiong Normal University, Yunnan Province, China.

\subsection{Data collection}

To ensure the participants provide efficient and sufficient information in this study, saturation and informants criteria were necessarily considered. Glaser and Strauss (1967) suggested a theoretical principal, saturation is an appropriate method in selecting participants in qualitative research. To ensure the quality of data, filtering procedure helped the researcher to control data to be more specified. Accordingly, data collection in this research was ongoing. In- class observation was continually to collect and record relevant data. The point of saturation was when the information I collected presented repetitively and further information turned to be superfluous. By then observation was finished to collect data.

In this part, there were seven in- class observations taken in this section. Observation had been developed under the permit of the potential participants and been launched progressively and continuously. During the process of classroom observation, lectures' interactions, language use, cultural experiences interactions had been recorded by taking in-class observation fieldnotes. Data from the fieldnotes was quoted and categorized.

\section{Findings}

In order to analyze data be more objectively, fieldnotes from the in-class observation were presented in a narrative way. Since findings in this qualitative analysis had been synthesized into thematic content, in which involves identifying themes and categories that collect from the original data, therefore, to discover sorts of categories and details in the observation fieldnotes, then to verify, to confirm and to filter the initial coding to identified norms for further study was necessary. Original data from the fieldnotes are transcribed literally, to illustrate what were the lecturer act in the class as the initial coding framework, then categorized into groups, then synthesized into themes. Themes were illustrated to find out the phenomenological norms. In this section, the rational contents of the themes were generally based on Diaz (2016) the three potentials of the linguaculture mentioned as the semantic and pragmatic potentials (Agar 1994), the poetic potentials, and the identity potentials.

\subsection{Semantic and pragmatic potential manifestation}

- $\quad$ Lecturer 1

As the coding presented that the lecturer's linguaculture implements affected language use in practical and language practices. From the process of the teaching, it illustrated that the lecturer applied several teaching methods. For instance, the lecturer explained the language use in practical and conduct student to comprehend the English use under the intercultural discourse to motivate the students to use English more often in the class.

... explain the teaching items in the graphic

... conducted students to the topic in English...

... show typical pictures related to cross-culture awareness...

Meanwhile, the lecturer also applied personal linguaculture experience as a learning and teaching material in the class. By doing so, the language teaching could be more specific than textbook explanation, which eventually facilitate students in English learning indirectly. The teaching process inspired linguaculture 
potentials, especially in social variation of the language, and intercultural pragmatics.

... applying personal overseas experiences...

... illustrated with short story of the lecturer's overseas life-personal experience...

... Shared personal overseas experience as a case study to students- personal experience...

... use my experience and some related movies and cased to evoke and motivate the students' learning interest...

... Share with students that cultural settings and environments...

- $\quad$ Lecturer 2

Lecturer 2 questioned the students, and explained the language point with linguaculture in the class. Students were practiced in language practice and culture knowledges. Meanwhile, the lecturer suggested and shared personal language study experiences directly as a learning sample for the student, which supported the students' language practice, especially under an intercultural pragmatics.

... gave the question, and wait for the students to share and discuss among themselves...

... the lecturer explained with personal learning experience and perspective on English vocabulary learning...

... gave more examples, and conducted students to compare the intercultural difference...

... shared personal overseas' experience to students to make them understand more connotative meaning and exactly use in English discourse...

... suggested the students would better to understand the deep meaning from both the target language and mother language...

... mentioned the cultural aspects embraced in both target language and mother language also are inevitable in language learning...

- $\quad$ Lecturer 3

The lecturer 3 corrected the mistakes made by the students, then explained and suggested appropriate ways in translation study, this linguaculture incorporation stressed the language use in practical for the student. To incorporate and present semantic and pragmatic potentials in the linguaculture, the lecturer also explained the structures of language use and the role of culture in translation study to the students directly.

... point out some grammar and vocabulary weak point...

... explained 'dramatic is better than extreme in this translation content, because dramatic may give an astonishing image to show something turn to be a new way...

... explained in translation, especially translate document. Sentence pattern may help you to make an effective translation. Generally, in order to give a clear and direct information..

... suggested sentence structure differences can affect translation...

... Suggested culture is vital in translation and any forms of language communication...

Meanwhile, to make the students understand culture influence in the translation study, the lecturer also facilitated the students to compare certain cultural literature works in both Chinese and English, which enhanced the students' contrastive semantics in linguaculture study.

... take famous Chinese fiction novel, 'Journey to the West' as an example. Explained how to illustrate the culture gap, culture point in this novel, and explain how to deal with culture gap in translation is the key point in the translation...

- $\quad$ Lecturer 5

The lecturer 5 enquired students to think in their own way, and conducted them in learning process. These teaching methods directly implemented linguaculture practice, especially in the semantic and pragmatic potentials, which supported the student to practice language use appropriately in semantics and pragmatic.

... posted questions directly and asked students to think about...

... conducted students to make a brain-storming...

... the whole class was conducted by the lecturer, illustration and explanation in English...

- $\quad$ Lecturer 6

Obviously, the lecturer directly conducted students to use English language flexibly, which aimed to practice students' language competence. Meanwhile, the lecturer also implemented the linguaculture contents to supported the student indirectly in the class, for instance, discussed the language use and personal opinion, compared the language use in certain context, mentioned the role of the culture. These supports facilitated language use in practical in linguaculture incorporation in the class.

... conducted students to the questions about Shelly...

... allow students to discuss and share personal opinion...

... lead the whole class to understand the writing techniques...

... compared the connotation meaning of the capitalize vocabulary...

... lead students to appreciate the culture difference of expressions in the poem... 
- $\quad$ Lecturer 7

From the observation quote, the lecturer 7 generally applied teaching method directly to practice students' English language, to enhance their semantic and pragmatic potentials in linguaculture incorporation. The teaching process simply presented the linguaculture potential.

... lead the whole class reviewed the previous learning...

... taught the whole class in English, explain in Chinese following...

... introduced the background of the writer, then changed the topic to Prometheus...

... asked the whole class to check the background of Prometheus...

\section{2 poetic potential manifestation}

\section{- $\quad$ Lecturer 6}

Different from other lecturers, this lecturer emphasized the language users' literariness in linguaculture incorporation since it was British literature class. The lecturer directly led the class to understand, appreciate the British literature works by means of teaching methods and explanations. Therefore, the students' poetic potentials in linguaculture study were inspired eventually.

... lead the whole class understand the general structure of the poem, conducted students to compare the norms, the structures and literature significance to the Shakespeare's work...

... gave the general introduction on the rhythmical structure of the poem...

... lead the whole class to appreciate the poem in details. Analyzed the vocabs, structures...

\section{3 identity potential manifestation}

- $\quad$ Lecturer 1

Identity potential in linguaculture dimension was presented indirectly in the class. the lecturer varied language in interaction with the students, indirectly incorporate personal linguaculture experience in class, especially illustrate the social variation of the language, which indirectly implement linguaculture experiences to support the student practice language.

... give students hints of cross-culture awareness in the pictures, but without explicit explanation...

... Free talk with students for few minutes...

- $\quad$ Lecturer 2

From the observation, lecturer number two was interacting with the students before class. The process of interaction presented the lecturer integrated personal social variation of the language to make the lecturer and the students' identity be clearer and more identified.

... asked the students their previous learning, review or preview...

... suggested the students would better have review and preview before class...

Meanwhile, the lecturer encouraged the students to communicate, and mentioned the way of English learning in college, which supported the students to build personal language and identity in language learning and communication.

... the lecturer would like to encourage students to communicate in the class with different friends...

... mentioned that English learning in college is different from the students learned in high school, they have to fix they own way of learning...

- $\quad$ Lecturer 3

Lecturer 3 directly conversed with the students, which explained the lecturer integrated linguaculture via language variation in certain discourse to identify the language use and personal identity.

... "the weather recently is extremely hot, doesn't it?" asked the lecturer

... "yes, yes, too hot, I got burned in recent." Added the student B...

- $\quad$ Lecturer 4

The lecturer 4, as other lecturers did, interaction with the students, indirectly implemented linguaculture practice in the class. The variation of the language use in the interaction presented the lecturer support the class to build personal identity potentials eventually.

... cheered up with students in English loudly...

... talking about the daily routines...

... asked students recent study progress...

... shared personal English learning stories with the students..

- $\quad$ Lecturer 5

As to the lecturer 5, interactions, conductions, encouragement were the means to implement linguaculture practice in the class. This indirect implement presented in social variation of the language use. And 
conductions and encouragement facilitated the students to build their personal language use and identity setting.

... the lecturer talked with the students about recent life, study progress and other daily routines...

... encouraged those shy students to share their opinion...

... kept encouraging and conducting to inspire those shy students, to motivate them to speak...

- $\quad$ Lecturer 7

The lecturer also guided and encouraged the students to use their studied English language to communicate and share personal opinion, which aimed to help the students to build personal language behavior and form their linguaculture identity in class.

... encouraged students to learn more by themselves, and encouraged students to enjoy team work in language learning...

... guided the students to make their personal understandings to be clearer, and have their own critical thinking on language point...

\subsection{Conclusion of the in-class observation findings}

By analyzing and categorizing the quote from seven fieldnotes I had recorded, it could be defined generally into two themes, the content of linguaculture experiences and the way of incorporate linguaculture experience. As to the content of linguaculture experiences could be separated into the linguaculture potentials and linguaculture teaching. As to the incorporation way, it could be divided into two ways, one is direct incorporation, another way is indirect incorporation.

Based on the fieldnote analysis, linguaculture experiences generally have used to suggest students the way of learning English, or to motivate and inspire students in English class. Meanwhile, from the analyzing, most of the students were interested in the lecturers' suggestion and incorporation of linguaculture experience. During teaching, however, linguaculture experiences could not be incorporated directly in the teaching. By analyzing the behaviors, actions of the lecturer in the English class, it could be noticed that not all the linguaculture potentials were applied and presented in English class, it depended on the lecturer varied personal teaching method in the class and the course content.

\section{Summary}

By analyzing and categorizing the quote from seven fieldnotes, the lecturers' linguaculture experience implement supported the class in English language practice both directly and indirectly. Lecturers' teaching methods presented the linguaculture potentials in correspond. However, not all the linguaculture potentials had been implemented in the class. The lecturers' teaching methods and linguaculture potentials supported the class in English language practice depends on the student's language proficiency, the course content.

Suggested future study deep the data exploring, by varying the data collection instruments and data analysis method to further the data. Meanwhile, the student's perspective towards the linguaculture implement also could be considered in the future study.

\section{Reference}

Agar, M. (1994)) Language shock: understanding the culture of conversation. New York, Perennial. US.

Creswell, J.W. (2003) Research design, qualitative, quantitative, and mixed methods approaches $\left(2^{\text {nd }}\right)$. Sage Publications. CA, US.

Creswell, J.W. (2007) Qualitative inquiry, research design (2 $\left.{ }^{\text {nd }}\right)$. Sage Publications. CA, US.

Creswell, J.W. (2002) Educational research, planning, conducting, and evaluating qualitative and quantitative research. Pearson Education. NJ. US.

Diaz, R. A. (2016) Developing critical languaculture pedagogies in higher education, theory and practice. Shanghai Foreign Language Education Press. CN.

Dervin, F. \& Liddicoat, A.J. (2013) Linguistics for intercultural education. John Benjamins Publishing Company, USA.

Evans D. (2015) Language and identity, discourse in the world. Bloomsbury Academic, USA.

Friedrich, P. (1989) Language, ideology, a political economy. American anthropology 91 (2). 295-312

Fromkim, V., Rodman, R. \&Hyams, N. (2017) An introduction to language. Cengage Learning Inc., USA.

Harmer, J (2014) The practice of English language teaching ( $5^{\text {th }}$ ed). Pearson. England. UK.

Hennink, M., Hutter, I., \& Bailey, A. (2011) Qualitative research methods. Sage Publications. CA, US.

Jackson, J. (2012). The Routledge handbook of language and intercultural communication. Routledge Tylor \& Francis Group. NY

Kramsch, C. (2008) 'ecological perspectives on foreign language education'. Language teaching 41:389-408

Liddicoat, A. J. \& Scarino, A. (2013). Intercultural language teaching and learning. Wiley- Blackwell. OX, UK.

Merriam, S., Tisdell, E.J. (2016) Qualitative research, a guide to design and implementation. John Wiley\& Sons, 
Inc. US.

Nieto, S. (2010). Language, culture, and teaching, critical perspectives $\left(2^{\text {nd }}\right)$. Routledge Tylor \& Francis Group. NY

Risager, K. (2005) Languaculture as a key concept in language and culture teaching. In B.Preisler, A. Fabricius, H. Habeerland, S. Kjaerbeck and Risager K. (eds) The Consequences of Mobility (pp. 185-196). Roskilde: Roskilde University, Department of Language and Culture.

Risager, K. (2006) Language and culture: global flows and local complexities. Clevedon: Multilingual Matters. Seidhofer, B. (2015) Understanding English as a lingua franca. Oxford University Press. UK.

Scollon, R., Scollon, S. W., \& Jones, R. H.. (2012) Intercultural communication, a discourse approach $\left(3^{\text {rd }}\right)$. Blackwell Publishing Ltd. UK.

Sharifian, F. \& Jamarani, M. (2013) Language and Intercultural communication in the new era. New York, Routledge. US.

Sharifian, F. \& Palmer, G.B. (2007) Applied cultural linguistic. John Benjamins Publishing Company, USA. 